\title{
Neurokinin B-related Peptide Suppresses the Expression of GnRH I, Kiss2 and tac3 in the Brain of Mature Female Nile tilapia Oreochromis niloticus
}

\author{
Ye Hwa Jin ${ }^{1}$, Jin Woo Park ${ }^{2}$, Jung-Hyun Kim ${ }^{1}$, and ${ }^{\dagger}$ Joon Yeong Kwon ${ }^{1}$ \\ ${ }^{1}$ Dept. of Aquatic Life Medical Sciences, Sunmoon University, Asan 31460, Korea \\ ${ }^{2}$ Marine Ecosystem and Biological Research Center, Korea Institute of Ocean Science \& Technology, Ansan 15627, Korea
}

\begin{abstract}
Neurokinin B (NKB) and neurokinin B related peptide (NKBRP) belong to tachykinin peptide family. They act as a neurotransmitter and/or neuromodulator. Mutation of NKB and/or its cognate receptor, NK3R resulted in hypogonadotropic hypogonadism in mammals, implying a strong involvement of NKB/NK3R system in controlling mammalian reproduction. Teleosts possess NKBRP as well as NKB, but their roles in fish reproduction need to be clarified. In this study, NKB and NKBRP coding gene (tac3) was cloned from Nile tilapia and sequenced. Based on the sequence, Nile tilapia NKB and NKBRP peptide were synthesized and their biological potencies were tested in vitro pituitary culture. The synthetic NKBRP showed direct inhibitory effect on the expression of GTH subunits at the pituitary level. This inhibitory effect was confirmed in vivo by means of intraperitoneal (ip) injection of synthetic NKB and NKBRP to mature female tilapia (20 pmol/g body weight [BW]). Both NKB and NKBRP had no effect on the plasma level of sex steroids, E2 and 11-KT. However, NKBRP caused declines of expression level of GnRH I, Kiss2 and tac3 mRNAs in the brain while NKB seemed to have no distinct effect. These results indicate some inhibitory roles of NKBRP in reproduction of mature female Nile tilapia, although their exact functions are not clear at the moment.
\end{abstract}

Key words : NKB, pituitary culture, injection, gonadotropin, kisspeptin, sex steroids, reproduction

\section{INTRODUCTION}

NKB that belongs to the tachykinin family of peptides is a neurohormone related with endocrinological regulations of vertebrate reproduction. Tachykinin peptides were named after their ability to induce rapid contraction of gut tissue, and they act as a neurotransmitter and/or neuromodulator (Pernow, 1983; Maggio, 1988; Krause et al., 1989). There are three major tachykinin peptides, substance P (SP), neurokinin A (NKA) and NKB (Severini et al., 2002; Ebner et al., 2009). These peptides are derived by posttranslational proteolytic processing of preprotachykinins (PPTs) (Carter and Krause, 1990). PPT A encoded by tachykinin 1 ( $\operatorname{tac} 1)$ gene is processed into SP and NKA while PPT B encoded by tac3 (Tac2 in rodents) is processed into NKB (Kotani et al., 1986; Krause et al., 1987). Recently, NKB has been suggested to be a potential key player in the mechanism of gonadotropin releasing hormone $(\mathrm{GnRH})$ release in mammals. Supportingly, Topaloglu et al. (2009) demonstrated that a functional mutation of $\mathrm{NKB}$ or its cognate receptor, NK3R, in mammals resulted in the hypogonadotropic hypogonadism.

Vertebrates including fish have developed a sophisticated

\footnotetext{
Manuscript received March 2, 2016, Received in revised form March 8, 2016, Accepted March 14, 2016

${ }^{\dagger}$ Corresponding Author : Joon Yeong Kwon, Dept. of Aquatic Life Medical Sciences, Sunmoon University, Asan 31460, Korea. Tel. : +82-41-530-2284, E-mail : jykwon@sunmoon.ac.kr

This is an Open Access article distributed under the terms of the Creative Commons Attribution Non-Commercial License (http:// creativecommons.org/licenses/by-nc/3.0) which permits unrestricted non-commercial use, distribution, and reproduction in any medium, provided the original work is properly cited.
} 
neuroendocrine system that controls reproductive activities responding to the changes of external environments such as photoperiod, temperature, nutrition, etc. These changes initiate the onset of puberty and lead to gonadal development by regulating the secretion of $\mathrm{GnRH}$ from hypothalamus. However, the underlying mechanism which regulates the release of $\mathrm{GnRH}$ in hypothalamus has not been clearly understood. Through studies conducted for last two decades, arcuate nucleus (ARC) in mammalian hypothalamus was identified as a pivotal factor for the control of reproductive axis. In the ARC, NKB system showed a co-expression with kisspeptin, dynorphin, NK3R and estrogen receptor $\alpha$ $(\mathrm{ER} \alpha)$ and had a steroid sensitivity in diverse mammalian species (for a review see Rance et al., 2010). Particularly, these neurons in ARC were connected to the terminal of GnRH neuron in median eminence of hypothalamus in mouse, suggesting an anatomical frame that could account for how this neuron regulates the pulsatile release of $\mathrm{GnRH}$ via steroid feedback (for a review see Rance et al., 2010).

Contrast to the progress made in the study of NKB system in various mammals, most of functional studies on fish NKB are limited to a model species. Results from these studies suggest that NKB system and its function in fish could differ from mammalian system. For example, unlike mammals, in zebrafish, there are two NKB genes (tac3a and tac3b) and three NK3R genes (tac3ra, tac3rb and tac3rc) (Biran et al., 2012; Ogawa et al., 2012; Zhou et al., 2012). Besides, piscine tac3 genes code for two tachykinin peptides, NKB and an additional peptide, NKBRP (Biran et al., 2012; Ogawa et al., 2012; Zhou et al., 2012). In mature female zebrafish, treatment with NKB or NKBRP caused an increase of LH level in plasma (Biran et al., 2012), implying that the function of NKBRP as well as NKB is related to the control of reproduction in fish. Kisspeptins are also known to be associated with reproduction via the action of GnRH in mammals and fish (Navarro et al., 2011; Park et al., 2012). However, neurons expressing tachykinin genes (tac1, tac3a and tac $3 b$ ) in zebrafish brain did not express Kiss genes which code for kisspeptins (Ogawa et al., 2012), suggesting that NKB might act independently from kisspeptin in zebrafish. However, whether the findings obtained from zebrafish are applicable to other teleosts, particularly to aquaculture species, is not clear at the moment.

Nile tilapia (Oreochromis niloticus) was chosen as experimental animals in this study. This species is one of the major aquaculture species and being bred globally including South Korea. Since they are easy to breed in captivity and have strong disease tolerance, this fish has been widely used as a model species for the studies of low vertebrates. The objective of this study is to investigate the role of NKB and NKBRP in the control of HPG axis in this aquaculture species. In this study, Nile tilapia tac3 gene was identified and characterized. Based on this tac3 gene sequence, NKB and NKBRP peptides were synthetized and administered to pituitary cells or whole fish. Responses to these NKB and NKBRP peptides were studied by analyzing expressions of GTH subunit genes in the pituitary cells or expressions of GnRH I, Kiss2, tac3 and GTH subunits genes with the plasma levels of sex steroid hormones (E2 and $11-\mathrm{KT}$ ) in mature females.

\section{METHODS AND MATERIALS}

\section{Animals and peptide synthesis}

Experimental fish were produced from wild type Nile tilapia (O. niloticus) obtained from Chungju, Chungcheongbukdo in Korea. They were reared in a closed recirculating aquaculture system at $27 \pm 1^{\circ} \mathrm{C}$ under a controlled photoperiod (14L:10D) and fed twice a day.

Nile tilapia NKB, EMDDIFIGLM-NH2 (MW, 1183.4) and NKBRP, YNDLDYDSFVGLM-NH2 (MW, 1551.6) were synthesized and carboxyl terminus was amidated using custom peptide synthesis service and purified by HPLC to $>95 \%$ purity (Peptron, Korea). 


\section{In silico and molecular cloning, phylogenetic analysis} and sequence analysis

Conserved sequences of tac3 from various animal species were identified using ClustalW. Tilapia tac3 primer pair was designed based on these conserved sequences (F1, 5'GGAACATCCTGAAGAGATAT-3'; R1, 5'-CCTCAGCC TGCACTTGTTGA-3'; Tm, 50 ${ }^{\circ} \mathrm{C}$ ) for RT-PCR using brain cDNA from a male tilapia. The resultant PCR product was cloned and sequenced. The obtained partial tac 3 sequence (224 bp) matched well to a part of tilapia genome. This putative tilapia tac3 partial sequence were similar to those of grass carp (Ctenopharyngodon idella) and Antarctic toothfish (Dissostichus mawsoni). To find out full sequence of tac3 mRNA including 3' and 5'-UTR, the additional tilapia tac3 primer pair was designed based on the common sequences between grass carp and Antarctic toothfish (F2, 5'-TCTAGCCGATTCCACTCTACTT-3'; R2, 5'-GCTTTG TCTCCAGATAAAACCG-3'; Tm, 54 ${ }^{\circ} \mathrm{C}$ ). The whole sequence of putative tilapia tac 3 mRNA was then obtained by cloning and sequencing. The amino acid (aa) sequence obtained by ExPASy Translate Tool (http://www.expasy.ch/tools/dan. html) was used for conserved domains analysis (http://www. ebi.ac.uk/Tools/InterProScan/) and the putative peptides were predicted by PeptideMass program (http://web.expasy.org/ peptide_mass/). Tac3 protein sequence from various species were collected from GenBank, aligned by ClustalW and trimmed. The identical and similar residues in multiple aligned protein sequences were shaded by BoxShade (http:// www.ch.embnet.org/software/BOX_form.html).

\section{In vitro pituitary culture}

Juvenile Nile tilapia with mixed sex (BW, 5.01 $\pm 0.85 \mathrm{~g}$; GSI, $0.10 \pm 0.02 \%$ ) were anaesthetized with benzocaine (50 ppm), and their pituitaries were removed and individually incubated in a 96-well plate with $80 \%$ (v/v) Leibovitz L15 medium, $\mathrm{pH} 7.4,10 \%$ fetal bovine serum, $100 \mathrm{IU} / \mathrm{mL}$ penicillin, and $100 \mu \mathrm{g} / \mathrm{mL}$ streptomycin for 3 hours at $27^{\circ} \mathrm{C}$ in a dark culture condition to stabilize them. The initial medium were replaced by fresh medium with different concentrations of $\operatorname{NKB}(0.1$ and $10 \mu \mathrm{M})$ or NKBRP $(0.01,0.1$ and $1 \mu \mathrm{M})$ peptide. After 6 hours, incubated pituitaries were collected for analysis. Viability of incubated pituitaries was confirmed by $0.4 \%$ trypan blue staining which showed that pituitaries were viable over 24 hours in this culture system. The pituitary glands were homogenized and total RNAs were extracted by TRI REAGENT ${ }^{\circledR}$ (Molecular Research Center, Inc., USA). cDNAs were synthesized from $1 \mu \mathrm{g}$ of the total RNAs with M-MLV reverse transcriptase (Promega, USA) and oligo $\mathrm{d}(\mathrm{T})_{15}$ primer (Promega).

Relative expression level of FSH $\beta$ and LH $\beta$ mRNA was investigated using quantitative real-time PCR reactions (qRT-PCR). GAPDH was used as a reference gene for normalization of FSH $\beta$ and LH $\beta$ expression levels. qRTPCRs were assayed using SsoAdvanced ${ }^{\mathrm{TM}}$ SYBR $^{\circledR}$ Green Supermix (Bio-Rad, USA) and CFX96 Touch ${ }^{\mathrm{TM}}$ RealTime PCR Detection System (Bio-Rad) in a $15 \mu \mathrm{L}$ reaction mixture containing $5 \mu \mathrm{L}$ cDNA (1:50 dilution), $7.5 \mu \mathrm{L}$ SsoAdvanced ${ }^{\mathrm{TM}} \mathrm{SYBR}^{\circledR}$ Green Supermix, $250 \mathrm{nM}$ forward and reverse primers (Table 1) and nuclease free water (N.F.W) up to $15 \mu \mathrm{L}$. The thermocycle profile was of $95^{\circ} \mathrm{C}$ for $30 \mathrm{sec}$ and 40 cycles of $95^{\circ} \mathrm{C}$ for $5 \mathrm{sec}$ and $60^{\circ} \mathrm{C}$ for 30 sec, and melting curve analysis was included at the end of last cycle. Each expression value of the mRNAs was presented as $\mathrm{Ct}$ (threshold cycles) values. The abundance level of the mRNAs was normalized against the amount of GAPDH and the relative abundance was determined by the comparative threshold cycle method, $2^{-\triangle \triangle \mathrm{Ct}}$, using CFX Manager ${ }^{\text {TM }}$ Software (Bio-Rad).

\section{In vivo injection}

To figure out the effect of NKB and NKBRP peptides on the brain-pituitary-gonad axis, 6-8 of mature female Nile tilapia (BW 60.18 \pm 10.97 g, GSI 4.48 $\pm 1.37 \%$ ) were anaesthetized with benzocaine $(50 \mathrm{ppm})$ and their blood 
Table 1. Primers used for quantitative real-time PCR (qRT-PCR)

\begin{tabular}{|c|c|c|}
\hline & Sequence & $\begin{array}{l}\text { Product } \\
\text { size }\end{array}$ \\
\hline Tac3 F & 5'-CTT ATG GGA CGG AGA AAC GC-3' & \multirow{2}{*}{$96 \mathrm{bp}$} \\
\hline Tac3 R & 5'-CCT CAG CCT GCA CTT GTT GA-3' & \\
\hline $\mathrm{LH} \beta \mathrm{F}$ & 5'-GCT GTC ACC CAG TAG AGA-3' & \multirow{2}{*}{$79 \mathrm{bp}$} \\
\hline LH $\beta$ R & 5'-TTG CTG AAT GGT ATC TTG ATG A-3' & \\
\hline GnRH I F & 5'-CTC GCA GGG ACG GTG TTT-3' & \multirow{2}{*}{$70 \mathrm{bp}$} \\
\hline GnRH I R & 5'-TCT TCC CTC CTG GGC TCA GT-3' & \\
\hline $\mathrm{FSH} \beta \mathrm{F}$ & 5'-GGC TTC GTC GAC ACC ACC AT-3' & \multirow{2}{*}{$148 \mathrm{bp}$} \\
\hline $\mathrm{FSH} \beta \mathrm{R}$ & 5'-TGA AAC CCC GTG GAC ATT GC-3' & \\
\hline Kiss2 F & 5'-CTA CTG GCT TTG GCT GTG GT-3' & \multirow{2}{*}{$112 \mathrm{bp}$} \\
\hline Kiss2 R & 5'-CTG CTC CTG TTG CAT GTG TT-3' & \\
\hline GAPDH F & 5'-TTA AGG AAG CCG TCA AGA AG-3' & \multirow{2}{*}{$126 \mathrm{bp}$} \\
\hline GAPDH R & 5'-CAG CAC CAG CAT CAA AGA-3' & \\
\hline$\beta$-actin $\mathrm{F}$ & 5'-AGC ATC CCG TCC TGC TCA CA-3' & \multirow{2}{*}{$121 \mathrm{bp}$} \\
\hline$\beta$-actin R & 5'-AGC ACA GCC TGG ATG GCA AC-3' & \\
\hline
\end{tabular}

was withdrawn $\left(\mathrm{T}_{0}\right)$ by heparinized syringes before hormones or vehicle injection. Synthetic Nile tilapia NKB, NKBRP or synthetic salmon luteinizing hormone releasing hormone (LHRH, as a positive control) (Sigma-aldrich, USA) at the concentration of $20 \mathrm{pmol} / \mathrm{g} \mathrm{BW}$, or PBS (as a negative control) was injected into the peritoneal cavity (peptide concentrations were decided based on Biran et al. (2012) for NKB and NKBRP and Levavi-Sivan et al. (2004) for LHRH, respectively) of mature female. After 6 hours, all experimental fish were anaesthetized, blood was withdrawn $\left(T_{1}\right)$, the brain and pituitary were removed for total RNA extraction, and the ovary was weighed and fixed in $10 \%$ formalin for histological observation.

Protocols for total RNA extraction and cDNA synthesis for the brain and pituitary tissues were the same as above. To examine the effect of NKB and NKBRP on reproduction, various genes related to reproduction were investigated using qRT-PCR, which include GnRH I, Kiss2 and tac3 in the brain and FSH $\beta$ and LH $\beta$ in the pituitary. Two housekeeping genes, $\beta$-actin and GAPDH were used as reference genes for normalization of each target gene expression level. qRT-PCR reactions were assayed in a $15 \mu \mathrm{L}$ reaction mixture containing $5 \mu \mathrm{L}$ cDNA (1:50 dilution), $7.5 \mu \mathrm{L}$ QuantiMix SYBR, $250 \mathrm{nM}$ forward and reverse primers (Table 1) and N.F.W up to $15 \mu \mathrm{L}$. The thermocycle profile was of $95^{\circ} \mathrm{C}$ for $10 \mathrm{~min}$, and 40 cycles of $95^{\circ} \mathrm{C}$ for $15 \mathrm{sec}$, $60^{\circ} \mathrm{C}$ for $15 \mathrm{sec}$, and $72^{\circ} \mathrm{C}$ for $15 \mathrm{sec}$ and melting curve analysis was included at the end of last cycle. Each expression value of the mRNAs was presented as $\mathrm{Ct}$ values. The abundance level of the mRNAs was normalized against the amount of $\beta$-actin and GAPDH.

To measure the effect on plasma level of E2 and 11-KT, enzyme-linked immunosorbent assay (ELISA) was conducted according to the manufacturer's protocols of Fish Estradiol (E2) ELISA kit $\left(\mathrm{CUSABIO}^{\circledR}\right.$, China) and Fish 11-keto testosterone ELISA kit $\left(\mathrm{CUSABIO}^{\circledR}\right)$. The plasma levels of E2 and 11-KT at 6 hours after the injection $\left(\mathrm{T}_{1}\right)$ and right before the injection $\left(\mathrm{T}_{0}\right)$ were read at $450 \mathrm{~nm}$ using EMax $^{\circledR}$ Endpoint ELISA Microplate Reader (Molecular Devices, Sunnyvale, CA) and calculated using logistic (log-log) curve-fit standard curve $\left(\mathrm{R}^{2}>0.99\right)$ which were generated by SOFTmax Pro 4.0 software (Molecular Devices).

Reproductive stage of fish used in this study was examined by a routine histological method. Paraffin-embedded ovarian tissues were sectioned at 6-7 $\mu \mathrm{m}$ and stained with hematoxylin and eosin. The slides were observed under a light microscope. The images were captured by a camera (Leica 300FX) and analyzed by a software (Leica Microsystems $\mathrm{GmbH}$, Germany). The stage of oocyte development was classified according to criteria given by Coward \& Bromage (1998).

\section{Statistical analyses}

Data were presented as mean \pm S.E.M. Statistical significance in gene expression in experimental groups was determined 
using independent $t$-test $(p<0.05)$ compared with that in negative control group. Analyses were performed using SPSS version 18.0.

\section{RESULTS}

\section{Identification of tilapia tac3 gene}

Nile tilapia tac3 gene contains 372 bp open reading frame (ORF) which encodes a PPT B of 123 aa (Fig. 1).

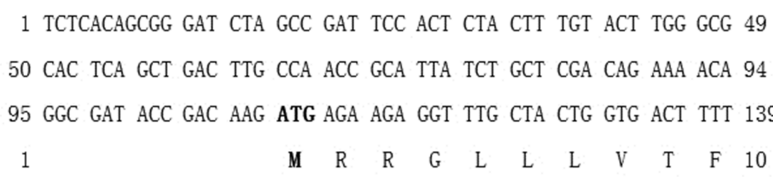

140 TTC CTC GTC ATG GAA TTT CGC TAC AGC CGG TGC AGA TGC GAC GAG 184 $\begin{array}{llllllllllllllllll}11 & F & L & V & M & E & F & R & Y & S & R & C & R & C & D & E & 25\end{array}$ 185 CCC GGA TCG CGC AGA TCA ACT TCA GAC CAG ACC ATA GGC TTA GAG 229 $\begin{array}{lllllllllllllllll}26 & P & G & S & R & R & S & T & S & D & Q & T & I & G & L & E & 40\end{array}$ 230 AAC TTT AAG CGG AAC ATC CTG AAG AGA TAT AAT GAC TTG GAT TAT 274 \begin{tabular}{llllllllll|lllllll}
41 & $\mathrm{~N}$ & $\mathrm{~F}$ & $\mathrm{~K}$ & $\mathrm{R}$ & $\mathrm{N}$ & $\mathrm{I}$ & $\mathrm{L}$ & $\mathrm{K}$ & $\mathrm{R}$ & $\mathrm{Y}$ & $\mathrm{N}$ & $\mathrm{D}$ & $\mathrm{L}$ & $\mathrm{D}$ & $\mathrm{Y}$ & 55
\end{tabular} 275 GAC AGC TTT GTG GGT CTG ATG GGG AGA AGA AGT GCA GAG GCT GAC 319 $\begin{array}{llllllllllllllllll}56 & \text { D } & \text { S } & \text { F } & \text { V } & \text { G } & \text { L } & \text { M } & \text { G } & \text { R } & \text { R } & \text { S } & \text { A } & \text { E } & \text { A } & \text { D } & 70\end{array}$ 320 GCT GAA CAA CCA CCC CAA AAA AGG GAG ATG GAT GAC ATT TTT ATT 364 $\begin{array}{llllllllllllllllll}71 & \mathrm{~A} & \mathrm{E} & \mathrm{Q} & \mathrm{P} & \mathrm{P} & \mathrm{Q} & \mathrm{K} & \mathrm{R} & \mathbf{E} & \mathrm{M} & \mathbf{D} & \mathbf{D} & \mathrm{I} & \mathbf{F} & \mathrm{I} & 85\end{array}$ 365 GGA CTT ATG GGA CGG AGA AAC GCA GAG ACT GAT AAT GGT CCC TGG 409 $\begin{array}{lllllllllllllllll}86 & \text { G } & \text { L } & \text { M } & \text { G } & R & R & N & A & E & T & D & N & G & P & W & 100\end{array}$ 410 AGG AGA GAG TAT CCA GAG AGG AGG GGC ATT TTT CTC AAC AAG TGC 454 $\begin{array}{llllllllllllllllll}101 & R & R & E & Y & P & E & R & R & G & I & F & L & N & K & C & 115\end{array}$ 455 AGG CTG AGG TTA CTT CAG GGA CTG TAG ACA CTG AGA GTT ACT TTC 499 $\begin{array}{llllllllllll}116 & \text { R } & \text { L } & \text { R } & \text { L } & \text { L } & \text { Q } & \text { G } & \text { L } & * & & 123\end{array}$ 500 ATT TGG CTA CAA TGA CAG AAT ATC ACC GAG AAC ATC AAC AGC AAA 544 545 CCA AAT GTC TGA TGG AAA CGA AAA AAC ACA TGT GAT TCC CAC TGT 589 590 ACC CGG CTT ATG AAA GTG ACA ATG TAC CAA GCA TAA TGT ACG GTT 634 635 TTA TCT GGA GAC AAA GCA TAA TTA GAA GTA ATA AAT TCT ATT TCT 679 680 TTA TCA TGT CAT TCT TTT TCT TAA ACT TCA AAA TAA ATG TAA TTT 724 725 TTT ATA

$$
730
$$

Fig. 1. Nucleotide and deduced amino acid sequence of NKB cDNA obtained from Nile tilapia (O. niloticus) brain. The open reading frame $372 \mathrm{nt}$ encodes a protein of 123 aa. Start (bold) and stop (*) codons are indicated. The NKBRP and NKB peptide are boxed with line and shaded, respectively. Cleavage and amidation signals are underlined.
Nile tilapia PPT B contains two NKB-like sequences; YNDLDYDSFVGLM $\left(50^{\text {th }}-62^{\text {th }}\right.$ aa $)$ and EMDDIFIGLM $\left(79^{\text {th }}-88^{\text {th }}\right.$ aa) (Fig. 1). The former is NKBRP, which is also termed as NKF (Biran et al., 2012; 2014), and the latter is NKB. These NKB-like sequences contain a common Cterminal sequence, -Phe-Ile/Val-Gly-Leu-Met, and a cleavage and amidation signal, -Gly-Arg-Arg (Fig. 1). In Nile tilapia genome, tac3 gene was found on GenBank acc. No. NT 167440.1 (1,122,918-1,124,713 nt). The genomic sequence of tac3 is comprised of seven exons and six introns. NKBRP and $\mathrm{NKB}$ encoding regions are located in the $3^{\text {rd }}$ and $5^{\text {th }}$ exons, respectively. Multiple alignment of PPT Bs of various species is shown in Fig. 2. It showed that the NKB and NKBRP regions of PPT B are highly homologous to other teleost species, and NKBRP found in fish including Nile tilapia does not exist in mammalian PPT B (Fig. 2).

\section{In vitro effect of NKB and NKBRP at the pituitary} level

The expression levels of both FSH $\beta$ and $\operatorname{LH} \beta$ were not changed by NKB treatment at $0.1 \mu \mathrm{M}$ and $10 \mu \mathrm{M}$ (Fig. 3A, C). On the other hand, NKBRP treatment significantly down regulated the expression level of FSH $\beta$ at 0.01 and $1 \mu \mathrm{M}$ and those of $\mathrm{LH} \beta$ at $0.01,0.1$ and $1 \mu \mathrm{M}$ (Fig. 3B, D).

\section{In vivo effect of NKB and NKBRP in female reproduction}

In the brain, GnRH I, Kiss2 and tac3 genes were investigated using qRT-PCR at 6 hours after ip injection of NKB, NKBRP or LHRH at $20 \mathrm{pmol} / \mathrm{g} \mathrm{BW}$ or PBS. GnRH I and tac3 mRNA expression levels were significantly decreased only in NKBRP injection group compared to those of PBS injection group (Fig. 4A, C). The amount of Kiss2 transcripts was decreased in both LHRH and NKBRP injection groups (Fig. 4B). A significant increase of LH $\beta$ expression was only shown in the LHRH injection group, while both NKB and NKBRP injection showed no significant effect 


grass carp
Atlantic salmon
medaka
channel catfish
grass rockfish
Arctic cod
rainbow smelt
zebrafish
Nile tilapia
Human
Gibbon
Monkey
Dog
Pig
Rat
Mouse
grass carp
Atlantic salmon
medaka
channel catfish
grass rockfish
Arctic cod
rainbow smelt
zebrafish
Nile tilapia
Human
Gibbon
Monkey
Dog
Pig
Rat
Mouse

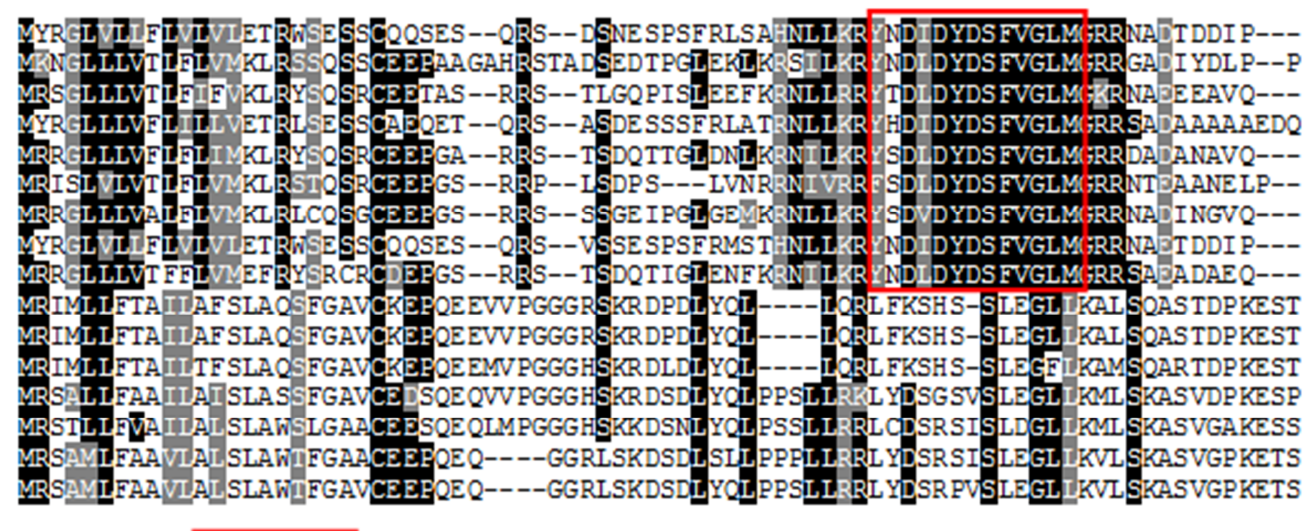

Fig. 2. Alignment of tac3 amino acid sequences from various vertebrates. The consensus amino acids are indicated by dark shade and similar residues are indicated by light shade. The regions within boxes indicate a NKBRP and NKB peptide, respectively. GenBank accession numbers of tac3 amino acid sequences are as follows: Ctenopharyngodon idella, grass carp (AEK66724.1); Salmo salar, Atlantic salmon a (DAA35154.1); Oryzias latipes, medaka (DAA35166.1); Ictalurus punctatus, channel catfish (DAA35153.1); Sebastes rastrelliger, grass rockfish (DAA35157.1); Boreogadus saida, Arctic cod (DAA35161.1); Osmerus mordax, rainbow smelt (DAA35163.1); Danio rerio, zebrafish a (AEK94815.1); Homo sapiens, human (AAH32145.1); Nomascus leucogenys, Northern white-cheeked gibbon (XP_003252831.1); Macaca mulatta, Rhesus monkey (XP_001115535.1); Canis lupus familiaris, dog (XP849031.2); Sus scrofa, pig (AAV32522.1); Rattus norvegicus, rat (NP062035.1); Mus musculus, mouse (NP033338.2).

on the amount of $\operatorname{LH} \beta$ and $\mathrm{FSH} \beta$ transcripts in mature female pituitary (Fig. 4D, E). After the injection, there were no significant differences in E2 and 11-KT plasma levels (data not shown). Gonadal reproductive stages of fish used in this study were in the stage of maturation and germinal vesicle migration.

\section{DISCUSSION}

\section{Identification of tilapia tac3 gene}

The complete cDNA sequence of tac3 gene in Nile tilapia was obtained by means of PCR cloning with the help from the genomic database of this species. This is, however, different from the result of Biran et al. (2014) which reported that tilapia tac 3 gene has ORF of 357 bp encoding 118 aa (GenBank accession No. KF471673 and AIG21810.1, respectively). They have identical NKB and NKBRP sequences; EMDDIFIGLM and YNDLDYDSFVGLM (Fig. 1), which have a highly conserved C-terminal sequence, Phe-X-Gly-Leu-Met-NH2 (Marksteiner et al., 1992). Their start codon is placed in the same position but the tac 3 gene identified in the present study has longer ORF of 372 bp 

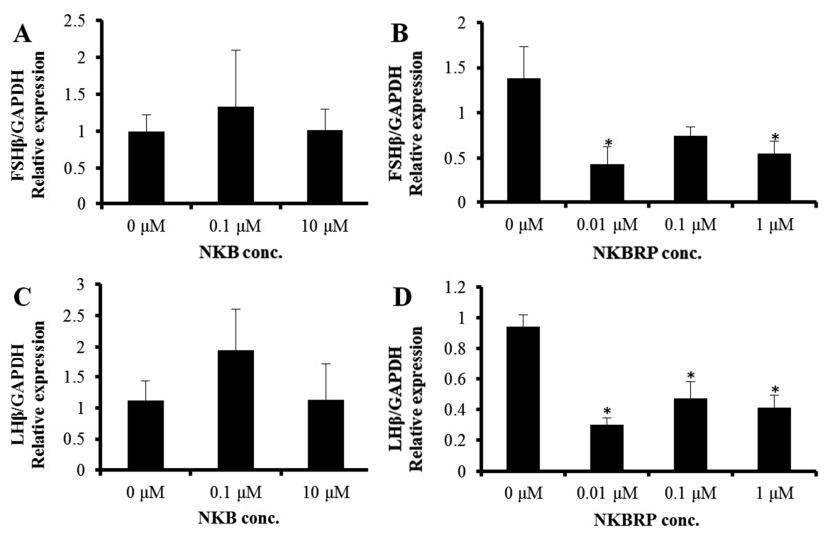

Fig. 3. Expression levels of FSH $\beta(A, B)$ and LH $(C, D)$ mRNAs in Nile tilapia pituitaries cultured with different concentrations of NKB $(A, C)$ or NKBRP (B, D) peptides. Relative abundance of the mRNAs was normalized to the amount of GAPDH by the comparative threshold cycle method using qRTPCR. Results are means \pm SEM $(n=5-8)$. * indicates significant difference from $0 \mu \mathrm{M}$ group $(P<0.05)$.
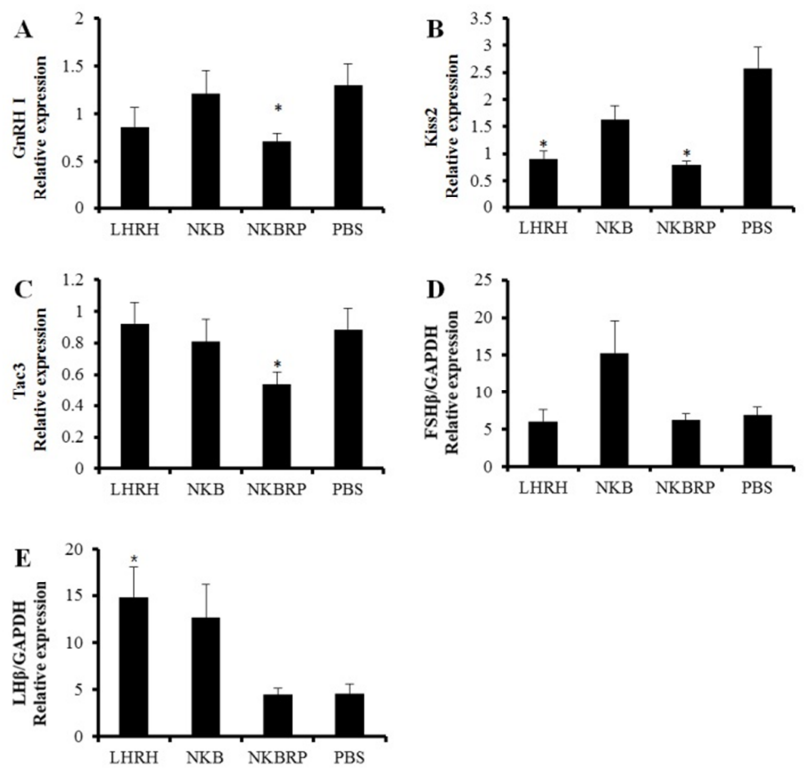

Fig. 4. Expression levels of GnRH I (A), Kiss2 (B) and $\operatorname{tac} 3(C)$ mRNAs in the brains and FSH $\beta$ (D) and LHß (E) mRNAs in the pituitaries of Nile tilapia injected either with LHRH, NKB, NKBRP or PBS. Relative abundance of the mRNAs in the brains was normalized to the amount of GAPDH and $\beta$-actin and in the pituitaries was normalized to the amount of GAPDH by the comparative threshold cycle method using qRT-PCR. Results are means \pm SEM $(n=6-8) . *$ indicates significant difference from PBS group $(P<0.05)$. encoding 123 aa identical to a predicted sequence in GenBank (mRNA, XM_005478084.2; protein, XP_005478141.

2) known to be located on linkage group 20. Sequence analysis revealed that Nile tilapia tac3 gene consists of seven exons, and NKBRP and NKB encoding regions are located in the $3^{\text {rd }}$ and $5^{\text {th }}$ exon, respectively. In zebrafish, there are two tac 3 genes, $\operatorname{tac} 3 a$ and $\operatorname{tac} 3 b$, and each gene also consists of seven exons and encodes both NKBRP and NKB (Biran et al., 2012; Ogawa et al., 2012; Zhou et al., 2012). However, Nile tilapia tac3b form gene could not be found in this study. The multiple alignment of tac 3 protein sequences showed that mammalian tac3 amino acid sequences contain a single NKB peptide (Fig. 2), implying that NKBRP peptide sequence probably disappeared during evolution in this lineage (Page et al., 2009).

2. In vitro effect of NKB and NKBRP at the pituitary level

To find out the direct effect of NKB and NKBRP on the expression of GTH subunit genes in the pituitary tissue, the expression levels of FSH $\beta$ and $\mathrm{LH} \beta$ in the tissue were measured by qRT-PCR after incubating the tissues with or without these peptides. In this study, the treatment of pituitary tissue with NKB peptide had no effect on the expression of GTH subunits. Interestingly, the pituitaries incubated with NKBRP peptide showed a significant decrease in the expression of both FSH $\beta$ and LH $\beta$ genes. This result, however, differ from the result of Biran et al. (2014), where administration of NKB and NKBRP (termed NKF) peptides to primary pituitary cell culture media induced increase of GTH release at specific concentration between 1 to 1,000 $\mathrm{nM}$. The discrepancy might be caused by the differences in the experimental methods. While in this study the whole intact pituitary tissues were cultured with peptides, Biran et al. (2014) disintegrated pituitary into cells and used the primary cells, which would allow to contact with peptides readily. In addition, the possible discrepancy between the 
expression level of GTH subunits mRNA and the amount of GTH release might cause the different result. Taken together with the direct effect of NKB and NKBRP on the release of GTHs, the result in this study showed that NKBRP may have an inhibitory effect on the expression of GTH subunits directly at the pituitary level.

\section{In vivo effect of NKB and NKBRP in female} reproduction

Pulsatile GnRH release has a crucial role in the activation of hypothalamus-pituitary-gonadal (HPG) axis (Wildt et al., 1980). However, the cause of $\mathrm{GnRH}$ release remains unclear. Recently, NKB is being considered as a new candidate for a GnRH pulse generator in hypothalamus of mammalian species. The functional mutation of NKB/NK3R also caused hypogonadotropic hypogonadism (Topaloglu et al., 2009), showing a potential involvement of NKB in the control of HPG axis. In ARC of hypothalamus in mammals, kisspeptin/ NKB/Dynorphin (KNDy) cells may serve as a central node in the control of GnRH secretion acting as conduits for a variety of intrinsic (e.g. internal hormones) and extrinsic regulatory signals (e.g. environmental cues) (for a review see Lehman et al., 2010). However, such co-expression of tac3 gene with Kiss genes was not observed in zebrafish (Ogawa et al., 2012), which implied an existence of a different mechanism to regulate pulsatile GnRH release in fish.

In NKBRP treated group in this study, the expression levels of GnRH I and Kiss2 mRNA in the brain were significantly decreased. Among three GnRHs, only GnRH I located in the preoptic area of hypothalamus in Nile tilapia implying its significance in reproduction of Nile tilapia (Parhar et al., 1996; Gothilf et al., 1996; Carolsfeld et al., 2000). The fact that the treatment with NKBRP decreased the expression of Kiss2 gene suggests a possible interaction between NKBRP and Kiss2 in this species, although there was no co-localization of Kiss genes with tachykinin genes in the brain of zebrafish (Ogawa et al., 2012).
Kiss2 gene expression level was reduced by LHRH injection in this study. A potential anatomical association of Kiss2 gene with GnRH was previously reported in tilapia, showing a co-expression of GnRH and GPR54, a cognate receptor of Kiss2 (Parhar et al., 2004). Thus, GnRH is thought to receive the signal of Kisspeptin via GPR54. The injection of LHRH, one of GnRHs, caused the significant increase of LH $\beta$ subunit expression in the pituitary as expected and the decrease of Kiss2 in the brain that might be downregulated through a negative feedback. The amount of tac3 transcript which encodes both NKB and NKBRP was decreased by the administration of NKBRP, implying some possible autoregulatory effects of NKBRP on its own coding gene.

The principal pituitary gonadotropins, FSH and LH, consist of two glycoproteins, a common $\alpha$ subunit and a unique $\beta$ subunit that confers biological specificity (Goodwin et al., 1983 and Godine et al., 1982). In LHRH treated group, the positive control, LH $\beta$ transcript level was significantly higher than that of control group. In vivo injection of $\mathrm{NKB}$ or NKBRP, however, had no effect on the expressions of GTH subunits in the pituitary, although in vivo injection of NKBRP had an inhibitory effect on GnRH I transcript level in the brain and in vitro treatment of NKBRP reduced the expressions of GTH subunits in the pituitary. The concentration of peptides (20 pmol/g BW) may not strong enough to stimulate the hypothalamus-pituitary axis in mature female Nile tilapia. In the same species but different sex, different results were reported by Biran et al. (2014). In male tilapia, ip injection of NKB or NKBRP increased the release of GTHs in vivo at specific concentration and timing. Injection of NKB at $10 \mu \mathrm{g} / \mathrm{kg} \mathrm{BW}(8.5 \mathrm{pmol} / \mathrm{g} \mathrm{BW})$ resulted in increased plasma level of both FSH $\beta$ and LH $\beta$ at 2 hours after the injection, while NKBRP at 10 and 100 $\mu \mathrm{g} / \mathrm{kg} \mathrm{BW}$ (6.4 and $64.4 \mathrm{pmol} / \mathrm{g} \mathrm{BW}$ ) had effect only on the release of $\mathrm{LH} \beta$ at 2 hours after the injection. In addition to the different dose of peptides, the sex of fish might also result in different effect. There were no data available about 
sex-specific difference of their function in fish but in some higher vertebrates. In ewes, NKB action on LH secretion varied depending on reproductive status, showing that NKB stimulates in the follicular but not the luteal phase (McManus et al., 2005). In addition, it also varied depending on endocrine status in adult female rats (Navarro et al., 2011; SandovalGuzmán \& Rance, 2004). To confirm this, further investigations on sex and life stage-specific effect of NKB and NKBRP peptides are required.

In conclusion, Nile tilapia tac3 gene and its molecular characteristics have been identified in this study. The result of in vitro pituitary culture demonstrated that Nile tilapia NKBRP peptide can inhibit the expression of GTH subunits. Furthermore, the injection of NKBRP suppressed the expression of GnRH I, Kiss2 and tac3 in the brain of mature female Nile tilapia in vivo. Both in vitro and in vivo results in this study suggested that NKBRP is involved in the control of reproductive axis, at least, at transcriptional level of the reproduction-associated genes, acting like an inhibitory substance in mature female Nile tilapia. So far as we understand, it is the first report that showed an inhibitory effect of NKBRP in teleost reproduction. Further studies are required to clarify any reproductive stage-specific, sex-specific or species-specific differences in the action of NKB and NKBRP in fish.

\section{ACKNOWLEDGEMENT}

This research was supported by Basic Science Research Program through the National Research Foundation of Korea (NRF) funded by the Ministry of Education (NRF2014R1A1A2058272).

\section{REFERENCES}

Biran J, Golan M, Mizrahi N, Ogawa S, Parhar IS, LevaviSivan B (2014) Direct regulation of gonadotropin release by Neurokinin B in tilapia (Oreochromis niloticus). Endocrinol 155:4831-4842.

Biran J, Palevitch O, Ben-Dor S, Levavi-Sivan B (2012) Neurokinin Bs and neurokinin B receptors in zebrafishpotential role in controlling fish reproduction. Proc Natl Acad Sci USA 109:10269-10274.

Carolsfeld J, Powell JFF, Park M, Fischer WH, Craig AG, Chang JP, Rivier JE, Sherwood NM (2000) Primary structure and function of three gonadotropin-releasing hormones, including a novel form, from an ancient teleost, herring. Endocrinol 141:505-512.

Carter MS, Krause JE (1990) Structure, expression, and some regulatory mechanisms of the rat preprotachykinin gene encoding substance $\mathrm{P}$, neurokinin $\mathrm{A}$, neuropeptide $\mathrm{K}$, and neuropeptide gamma. J Neurosci 10:2203-2214.

Coward K, Bromage NR (1998) Histological classification of oocyte growth and the dynamics of ovarian recurdescence in Tilapia zillii. J Fish Biology 53:285-302.

Ebner K, Sartori SB, Singewald N (2009) Tachykinin receptors as therapeutic targets in stress-related disorders. Curr Pharm Des 15:1647-1674.

Godine JE, Chin WW, Habener JF (1982) alpha Subunit of rat pituitary glycoprotein hormones. Primary structure of the precursor determined from the nucleotide sequence of cloned cDNAs. J Biol Chem 257:8368-8371.

Goodwin RG, Moncman CL, Rottman FM, Nilson JH (1983) Characterization and nucleotide sequence of the gene for the common alpha subunit of the bovine pituitary glycoprotein hormones. Nucleic Acids Res 11:6873-6882.

Gothilf Y, Munoz-Cueto JA, Sagrillo CA, Selmanoff M, Chen TT, Kah O, Elizur A, Zohar Y (1996) Three forms of gonadotropin-releasing hormone in a perciform fish (Sparus aurata): complementary deoxyribonucleic acid characterization and brain localization. Biol Reprod 55: 636-645.

Kotani H, Hoshimaru M, Nawa H, Nakanishi S (1986) Structure and gene organization of bovine neuromedin 
K precursor. Proc Natl Acad Sci USA 83:7074-7078.

Krause JE, Chirgwin JM, Carter MS, Xu ZS, Hershey AD

(1987) Three rat preprotachykinin mRNAs encode the neuropeptides substance $\mathrm{P}$ and neurokinin A. Proc Natl Acad Sci USA 84:881-885.

Krause JE, MacDonald MR, Takeda Y (1989) The polyprotein nature of substance $\mathrm{P}$ precursors. BioEssays 10: 62-69.

Lehman MN, Coolen LM, Goodman RL (2010) Minireview: Kisspeptin/Neurokinin B/Dynorphin (KNDy) cells of the arcuate nucleus: A central node in the control of gonadotropin-releasing hormone secretion. Endocrinol 151: 3479-3489.

Levavi-Sivan B, Safarian H, Rosenfeld H, Elizur A, Avitan A (2004) Regulation of Gonadotropin-Releasing Hormone $(\mathrm{GnRH})$-receptor gene expression in tilapia: Effect of GnRH and dopamine. Biol Reprod 70:1545-1551.

Maggio JE (1988) Tachykinins. Annu Rev Neurosci 11: $13-28$.

Marksteiner J, Sperk G, Krause JE (1992) Distribution of neurons expressing neurokinin $\mathrm{B}$ in the rat brain: Immunohistochemistry and in situ hybridization. J Comp Neurol 317:341-356.

McManus CJ, Valent M, Connors JM, Lehman MN, Goodman R (2005) A neurokinin - B Agonist Stimulates LT Secretion in Follicular, but not Luteal Phase Ewes. Abstract Viewer / Itinerary Planner, Washington, DC: Society for Neuroscience.

Navarro VM, Castellano JM, McConkey SM, Pineda R, Ruiz-Pino F, Pinilla L, Clifton DK, Tena-Sempere M, Steiner RA (2011) Interactions between kisspeptin and neurokinin $\mathrm{B}$ in the control of GnRH secretion in the female rat. Am J Physiol Endocrinol Metab 300:E202E210.

Ogawa S, Ramadasan PN, Goschorska M, Anantharajah A, $\mathrm{Ng} \mathrm{KW}$, Parhar IS (2012) Cloning and expression of tachykinins and their association with kisspeptins in the brains of zebrafish. J Comp Neurol 520:2991-3012.

Page NM, Morrish DW, Weston-Bell NJ (2009) Differential mRNA splicing and precursor processing of neurokinin B in neuroendocrine tissues. Peptides 30:1508-1513.

Parhar IS, Ogawa S, Sakuma Y (2004) Laser-captured single digoxigenin-labeled neurons of gonadotropin-releasing hormone types reveal a novel $\mathrm{G}$ protein coupled receptor (Gpr54) during maturation in cichlid fish. Endocrinol 145:3613-3618.

Parhar IS, Pfaff DW, Schwanzel-Fukuda M (1996) Gonadotropin-releasing hormone gene expression in teleosts. Mol Brain Res 41:216-227.

Park JW, Kim J-H, Jin YH, Kwon JY (2012) Expression profiles of Kiss2, GPR54 and GnRH recepter I mRNAs in the early life stage of Nile tilapia, Oreochromis niloticus. Dev Reprod 16:31-38.

Pernow B (1983) Substance P. Pharmacol Rev 35:85-141.

Rance NE, Krajewski SJ, Smith MA, Cholanian M, Dacks PA (2010) Neurokinin B and the hypothalamic regulation of reproduction. Brain Res 1364:116-128.

Sakai N, Iwamatsu T, Yamauchi K, Suzuki N, Nagahama Y (1988) Influence of follicular development on steroid production in the medaka (Oryzias latipes) ovarian follicle in response to exogenous substrates. Gen Comp Endocrinol 71:516-523.

Sandoval-Guzmán T, Rance NE (2004) Central injection of senktide, an NK3 receptor agonist, or neuropeptide $\mathrm{Y}$ inhibits LH secretion and induces different patterns of Fos expression in the rat hypothalamus. Brain Res 1026:307-312.

Severini C, Improta G, Falconieri-Erspamer G, Salvadori S, Erspamer V (2002) The tachykinin peptide family. Pharmacol Rev 54:285-322.

Topaloglu AK, Reimann F, Guclu M, Yalin AS, Kotan LD, Porter KM, Serin A, Mungan NO, Cook JR, Ozbek MN, Imamoglu S, Akalin NS, Yuksel B, O'Rahilly S, Semple RK (2009) TAC3 and TACR3 mutations in familial 


\section{NKBRP Downregulates GnRH I, Kiss2 and Tac3 Genes}

hypogonadotropic hypogonadism reveal a key role for Neurokinin B in the central control of reproduction. Nat Genet 41:354-358.

Wildt L, Marshall G, Knobil E (1980) Experimental induction of puberty in the infantile female rhesus monkey. Science 207:1373-1375.
Zhou W, Li S, Liu Y, Qi X, Chen H, Cheng CH, Liu X, Zhang Y, Lin H (2012) The evolution of tachykinin/ tachykinin receptor (TAC/TACR) in vertebrates and molecular identification of the TAC3/TACR3 system in zebrafish (Danio rerio). Mol Cell Endocrinol 361: 202-212. 